\title{
Deindustrialisation and the fear of relocations in the industry
}

\author{
Hervé Boulhol* - Lionel Fontagné\#
}

This version: 13 July 2005

\begin{abstract}
The steady decline in the share of industry in total employment currently seems to be accelerated by competition from low wage countries, which depresses international prices for manufactured products and is being translated into offshore outsourcing and defensive innovation. In order to fully address these issues, we define offshore outsourcing in a broader sense, the one which is generally adopted in the public debate, namely trade in goods with countries where offshoring takes place. We replicate and extend the estimations realised by Rowthorn and Ramaswami (1998) and ask what has been the responsibility of outsourcing in the observed deindustrialisation in sixteen OECD countries. Our estimation strategy, relying on a dynamic panel methodology, leads to the conclusion that net trade with low wage countries is associated with a non-negligible average decrease of around 2 points in the manufacturing employment share between 1970 and 2002. However, this contribution, which substantially varies across countries, represents only a fifth of the deindustrialisation over the period. We did not find any increased impact of imports from developing countries in the second half of the period (1986-2002), other than that due to increased trade.
\end{abstract}

Key words: deindustrialisation, trade, outsourcing JEL Classification 01, 03, F16, F43

\footnotetext{
* IX IS-CIB and Université de Paris I, hboulhol@ ixis-cib.com

\# CEPII and Université de Paris I, fontagne@ cepii.fr
} 


\section{INTRODUCTION}

International competition exhibits new patterns, characterised by the emergence of big new players and the acknowledged international relocation of industrial production in low-wage countries. How such pattems impact industrial employment in industrialised countries is a key issue for policy makers. Offshoring and outsourcing fill the columns of the newspapers, and the disconnection between the prudent diagnosis of the economic profession and the perception of the civil society is growing. The steady decline in the share of industry in total employment currently seems to be accelerated by the very forces of globalisation, which translates into a series of factories being dismantled, and at best for European countries being relocated to new low wage eldorados, namely the new Member States. Consequently, the civil society, as well as numerous commentators and politicians, are associating the phenomenon of offshore outsourcing, and more generally competition with the South, with the observed deindustrialisation, defined as the decline in the share of manufacturing in total employment. Such fears regularly feed the political debate (e.g. Arthuis report, 1993), especially when a downturn in economic activity matches the calendar of a political event: one may for instance recall that Ross Perot had predicted a "giant sucking sound" caused by the loss of 5 million US jobs to Mexico if Congress ratified the Agreement on the North American Free Trade Area (NAFTA).

The recent controversy between Samuelon (2004) and Bhagwati et al. (2004), should not hide that the perception of these evolutions by a large majority of economists is less alarming than the one of the civil society (e.g. Marin, 2004). D eindustrialisation is primarily a natural outcome associated with the development of modern societies, and resulting from demand, supply and relative price effects. Therefore, competition from the South (via specialisation or offshore outsourcing) is responsible for only a limited part of the above phenomenon. However, if specialisation and trade are the source of positive gains, adjustment costs can indeed be large and painful in certain regions or within certain parts of the population. Thus, the more rigid the economy, the slower the adjustments, the more pronounced the "local pains". All in all, whereas the public opinion perceives deindustrialisation, outsourcing, offshoring and the competition of emerging countries as the same frightening phenomenon, most professional economists consider deindustrialisation as mostly a "domestic issue" rather disconnected from international competition. 
However, since relative prices are at stake, one can hardly neglect another strand of argument. First, the new competitors, combining low labour costs with large productivity levels, thanks to the presence of foreign multinationals, definitely depress international priøs for manufactured products. Second, technical progress is not exogenous: Its application in factories is mainly driven by competitive pressure. D efensive innovation (Thoenig \& Verdier, 2002) might thus reinforce the natural evolution of productivity in the industrial sector.

As a result, even if offshore outsourcing plays a limited role in lay-offs, and deindustrialisation is mainly driven by internal forces, and the net factor content of our trade with the South remains limited, there could still be arguments highlighting the impact of competition from the South on the relative decline in the share of industry in total employment in the North. By better addressing this issue, which matches the concerns of the civil society, we hope to contribute to the clarification of the debate.

W e will define offshore outsourcing in a broader sense, the one which is generally adopted in the public debate, namely trade in goods with countries where offshoring takes plac. In the following, we replicate and extend the estimations realised by Rowthom and Ramaswami in their seminal 1998 paper (RR, hereafter) and ask what is the responsibility of outsourang in the observed deindustrialisation? First, RR 1963-1994 period is extended up to 2002 and second, our estimation strategy relies on a dynamic panel specification using G MM methodology. ${ }^{1}$

We will here limit our investigation to manufacturing, but one should keep in mind that offshoring of services is the other side of the coin: Amiti \& Wei (2004), van Welsum (2004) and GAO (2004) are seminal contributions as far as services are concerned. However, the kind of data and methodology to be used differs largely.

The rest of this paper is organised as follows. Section 2 gives an overview of the debate, Section 3 proposes a simple theoretical framework for estimation purposes, Section 4 provides descriptive statistics for a panel of industrialised countries, Section 5 discusses the results and Section 6 concludes.

\section{OVERVIEW OF THE DEBATE}

The very rapid development of the international division of labour, as fostered by the emengence of competitors with a very broad spectrum of comparative advantages in industrial activities (e.g. China), and sometimes in services too (e.g. India), has revived a leitmotiv in public debate in Europe, Japan and the 
United States: the "hoovering-up" of jobs by competition from low-wage economies as well as the future of the manufacturing industry.

In the United States, the "Manufacturing in America" report, commissioned by President Bush from the US D epartment of Commerce, reflects the concerns above. ${ }^{2}$ For the US Secretary of Commerce, "A merica's manufacturers provide our nation and our people with good jobs, a better quality of life, and inventions that have established our national identity. Manufacturing is the badk bone of our economy and the musde behind our national security". Such a statement echoes President Clinton's views, who set the objective of restoring manufacturing's share of US employment from $17 \%$ to $20 \%$. There is no need to quote European officials on the subject, as similar statements could easily be found.

\section{Intemational competition is playing a role}

Industry continues to play a key role in advanced economies: when the statistics are adjusted to take account of the development of temporary work, the outsourcing of certain services by manufacturers (cleaning, accounting, catering, etc.) and the increasingly blurred boundaries between services and manufacturing in many sectors, the manufacturing industry is in fact more or less maintaining its volume share of GDP. Many service activities owe their very existence to the presence of the manufacturing industry.

However, opening up the economy can contribute to the decline in - though not the disappearance of the manufacturing industry as a result of the combination of four phenomena.

First, the advantage of the old industrialised economies is currently shifting from the factory to the office, distribution network or trading desk. This means a growing specialisation in services and a commensurate decline in manufacturing in the face of rising competition from imports originating in the newly industrialised countries. The result would be a Nike-style industry, designing, importing and distributing the goods that it no longer manufactures.

Second, the downward pressure exerted by new competitors with very low labour costs and lax environmental rules may have a selection effect on firms, products and technologies in the North. Only the most productive firms will survive; only upmarket products with no competition from low-cost imports will hold their own; only the most productive, least labour-intensive technologies will be chosen. 
Third, firms reorganise themselves on a global level to take advantage of international cost differentials, specialising their overseas subsidiaries in different segments of the production process. The associated fragmentation of the production processes characterised by a growing recourse to imported parts and components from low-wage countries (Fontagné et al., 1996; Hummels et al., 2001): imports would be a complement of, rather than a substitute to, domestic inputs (Aw \& Roberts, 1985). This changing nature of trade, which exploits the modularity of products in order to benefit from the differences in costs between the various possible locations, had been on the cards for a long time (Sanyal, 1983; Sanyal \& Jones, 1982; D ixit \& Grossman, 1982). But it is the sharp fall in transaction costs (in particular plummeting communication costs) and the large scale opening-up of the South's economies that has unleashed all this potential.

Last, the new markets are in the South and factories are located near the markets. Thus, the shift in international demand to new areas, given the relative sluggishness of the EU economy, inevitably leads European manufacturers to locate their new capacities in the neighbourhood of these dynamic new markets.

Is there anything new about these phenomena? The answer is yes: though the emergence of new competitors is nothing new, the combination of substantial cuts in transaction costs with the opening-up of large economies, possessing an abundance of cheap labour that multinational corporations can tap using advanced technologies, smashes a hole in the logic behind the division of labour between North and South.

\section{Arguments downplaying those fears}

Economic analysis recalls that deindustrialisation is above all an internal development in the advanced economies. Second, the direct impact of international competition with the South on the employment level in the North is limited, notwithstanding potentially visible distributive impacts between categories of workers.

The grounds of the former argument are as follows. The structure of household demand is impacted by increasing purchasing power. During a lengthy industrialisation phase, the spread of industrial goods in the society combines with the industrialisation of certain tasks (noticeably regarding housekeeping) and, possibly, a taste for material goods: the income elasticity of demand for industrial goods is high. As needs 
are saturated and personal wealth increases, society dematerialises, consumption shifts to services and the sale of material goods includes a growing service content. The income elasticity of demand for industrial goods diminishes. This demand effect combines with a supply effect. Indeed, technological developments bring faster productivity gains in manufacturing than in services. This is because, roughly speaking, the production process in industry can more easily automate tasks, whereas some services must take into account personal characteristics and manage more complex information. The resulting change in relative prices increases the consumption of material goods through a substitution effect. Up to a certain level of income, the above two effects combine to increase volume demand for manufactured goods and so the volume of manufacturing output; above that level, the substitution effect sustains stagnant or falling demand for industrial products. Manufacturing industry holds its own in terms of volume, but its share in the production of value - and therefore of jobs - diminishes. The decline of manufacturing industry's share of total employment is therefore inexorable.

Regarding the second strand of the argument, the issue of the hoovering-up of jobs by trade was definitively covered by Lawrence \& Slaughter (1993). Basically, the developing countries' share of the leading industrialised countries' trade remains too small for imports from those countries to be the main determining factor in labour-market trends in the North. Hine \& Wright (1998), for example, found a limited impact of imports on UK employment, around 6\% of job losses in the manufacturing sector over the period 1981-91. Sachs and Shatz (1994) estimated that developing country trade is associated with a decline of 5.7\% in manufacturing employment in the USA between 1978 and 1990, period during which the share of manufacturing in employment has decreased by $27 \%$. Although there has been an appreciable divergence in pay or employment between skill groups in the old industrialised countries, technical progress (which is biased against unskilled labour) is the likeliest suspect. However, technological progress itself is not of an exogenous nature: it is, on the contrary, impacted by the competitive pressure.

\section{How best to trace the phenomenon?}

Offshore outsourcing is a major issue for which we lack a definition precisely setting the boundaries of the empirical studies. The "closing-down-followed-by-relocation-abroad-in-order-to-import" criterion, often associated with the French notion of "délocalisation", is by definition too narrow and hardly corresponds to any statistical category or any sizeable phenomenon. The bulk of the phenomenon is of a different nature, which is why a different kind of criterion is generally used, based on the matrix of alternatives 
contemplated by the firm. The first alternative is "within the firm versus outside the firm" (the traditional "make or buy" dilemma), and it puts emphasis on outsourcing - be it domestic or not. The second alternative is to produce (or buy) domestically versus resorting to production abroad. Accordingly, offshoring of activities to foreign affiliates, or offshore outsourcing, are the two faces of a same coin: the location of a fraction of the value added chain abroad (in a low wage economy).

In order to trace the impact of such fragmentation on the domestic economy, the best strategy would be to compile individual firm data. The problem is that such data is simply not available on a comparative basis for OECD countries as a whole: we therefore face the risk of drawing conclusions on the basis of limited evidence. An altemative is to rely on Input-O utput coefficients (eventually combined with trade data) in order to trace intermediate imports and their evolution over time (Feenstra and Hanson 1996 \& 1999, Anderton \& Brenton, 1999, Strauss-Kahn 2003, Hijzen et al. 2003). O nce again, we are constrained by the availability of the data and by the different nomenclatures of activity.

There is of course yet another possibility, which is to rely on trade data only. The drawback of such an approach is of course that, besides the imports of intermediates associated with offshore outsourcing, besides the imports of final products assembled in foreign subsidiaries or by subcontractors, we also record the exports of low wage countries which simply result from their specialisation. China is exporting tee shirts because Nike is subcontracting there, but also because China is exporting the kind of products it is advantaged in, namely labour intensive products such as tee shirts. However, given the shape of the debate in our countries, we will tentatively embrace such an approach. After all, the civil society is talking about offshoring, outsourcing, "délocalisations" quite indifferently and is interpreting arm's length exports of Chinese clothing manufacturers as a part of this broad phenomenon. The same for deindustrialisation, as stressed by Krugman: «Let me call (... ) the view that the loss of high-wage manufacturing jobs due to foreign trade (as opposed to purely domestic shifts in demand or technology) has been a major cause of stagnating or declining incomes among American workers, the deindustrialization hypothesis ».3 All in all, if such empirical strategy points to a limited impact of imports from the South in the deindustrialisation process, we will not be accused of downsizing the phenomenon: what we will be considering is an upper limit of the phenomenon at stake.

Actually, such avenue of research was initially explored by the IMF. Using data for 18 industrialised countries over the period 1963-1994, RR estimated that a one percentage point increase in imports from 
low wage economies translated into an $8.5 \%$ increase in the relative productivity of manufacturing in importing countries. This effect on productivity being controlled, the depressive impact on prices of import from low wage countries is no longer significant. Beside, regressing the relative employment in manufacturing (which is an inverse measure of deindustrialisation) on income per capita, openness and investment, they found that the contribution of trade with low wage economies is $20 \%$ at most. In total, over the 1970-1994 period, net imports from low wage economies would have (indirectly through their impact on productivity in the North) displaced $1.6 \%$ of the industrial jobs in the North. Accordingly, the increasing competition from the South would have displaced no more jobs throughout the OECD in 25 years than the USeconomy creates within three months.

This seminal work, besides some econometric issues left pending, has a major drawback: it does not take into account the recent period, characterised by an acceleration of the participation of emerging economies in world trade. Hence the need to update this kind of study regularly in order to check out whether such an order of magnitude continues to make sense.

\section{A SiMPLE MODEL WITH TWO SECTORS}

\section{Relative prices and productivity}

There are two sectors in the economy, industry I and services S. The production functions are: $Y_{j}=A_{j} . L_{j}$ with $\mathrm{j}=\mathrm{I}, \mathrm{S}$.

For each sector, L stands for employment, Y production, A total factor productivity (TFP). TFP is supposed to be growing at an exogenous rate $g_{I}$ in industry and $g_{S}$ in services, with $g_{I}>g_{S}$. Relative labour productivity and price are denoted RE L PROD and RE L PR ICE respectively:

$$
\begin{aligned}
& R E L P R O D \equiv\left(Y_{I} / L_{I}\right) /\left(Y_{S} / L_{S}\right)=A_{I} / A_{S}=A_{0} \cdot e^{\left(g_{I}-g_{S}\right) \cdot t} \\
& \text { RELPRICE } \equiv p_{I} / p_{S}
\end{aligned}
$$

The first-order conditions imply:

$$
\log (R E L P R I C E)=c t e-\log (R E L P R O D)
$$


The rise in the relative productivity of industry is totally passed on the relative price. Taking into account capital and extending production functions to the case of constant elasticity of substitution, $\sigma$, would lead to:

$$
\log (R E L P R I C E)=c t e-\log (R E L P R O D)+\alpha \cdot(1-1 / \sigma) \cdot \log (w / r)
$$

where $\alpha$ is a constant, positive if the industrial sector is relatively intensive in capital, negative otherwise, and where $\mathrm{w} / \mathrm{r}$ is the relative factor cost. When taking into account the upward trend in relative wages, relative prices falls slightly less than relative productivity increases if the elasticity of substitution between capital and labour is lower than 1.

\section{E mployment, value added at constant and current prices}

On the demand side, utility is supposed to be CES of elasticity $\eta$ between industrial goods and services. Therefore, relative demand will verify:

$$
\log \left(X_{I} / X_{S}\right)=c t e-\eta \cdot \log \left(p_{I} / p_{S}\right)
$$

This simple model leads to the following results. First, combining (1), (2) and (3), relative employment is given by:

$$
\log \left(L_{I} / L_{S}\right)=c t e-(1-\eta) \cdot\left(g_{I}-g_{S}\right) \cdot t
$$

from which the trends in the relative share of industrial employment are deduced:

$$
\frac{L_{I}(t)}{\bar{L}(t)}=\frac{1}{1+L_{S}(0) / L_{I}(0) \cdot e^{\left(g_{I}-g_{S}\right) \cdot(1-\eta) \cdot t}}
$$

where $\bar{L}$ stands for the total labour force. The elasticity of substitution $\eta$ plays a key role in the deindustrialisation. With $\eta$ lower than unity, as the estimates confirm, the substitution between industrial goods and services will not be large enough to compensate the decrease in the relative price resulting from higher productivity gains in the industry. Consequently, the share of industry in the labour force decreases towards zero because of productivity gains (in practice, because of the heterogeneity of industrial sectors, productivity in industry slows until it is balanced with productivity in services, and industrial employment eventually stabilises). The pace of deindustrialisation is slowed if the elasticity of substitution between goods and services is strong: with the fall in prices, demand for manufactured goods (in volume terms) 
increases all the more so as $\eta$ is high and industrial employment declines at the pace $\left(g_{I}-g_{S}\right) \cdot(1-\eta)$. With an elasticity of substitution of around 0.5 , a $1.5 \%$ per year increase in relative productivity entails a 0.75\% per year decline in relative employment.

Second, equations (2) and (3) imply:

$$
\frac{p_{I} \cdot X_{I}}{p_{S} \cdot X_{S}}=c t e \cdot \frac{X_{I} / A_{I}}{X_{S} / A_{S}}=c t e \cdot \frac{L_{I}}{L_{S}}=\operatorname{cte} .\left(p_{I} / p_{S}\right)^{1-\eta}
$$

Relative industrial employment moves in lockstep with relative industrial value-added (in value terms), and this corresponds to the stylised facts, as documented in Section 4.

Third, the economy growth's rate converges in the long term towards growth in the least buoyant sector, in other words services, i.e. $g_{S}$. Growth decelerates but from a high level of wealth: there is no other possible growth path. 4

\section{Turning point}

The main flaw of the model consists in the forecasts about relative value-added in volume terms. For, according to equation (3), the fall in industry prices should lead to a continuous rise in relative industry output, and this does not seem to be borne out by the data, highlighting further a distortion in demand related to development (see Section 4). To introduce this wealth effect and building on RR, Engel's law could be extended to industrial goods. According to Engel's law, the relative consumption (in volume terms) of agricultural products decreases from a certain level of development. In other words, at constant relative price, the relative demand of industrial goods follow a hump shape based on the level of development. To take this effect into account, real GDP per capita at PPP, Y CA P, is introduced in the relative demand equation:

$$
\begin{aligned}
& \log \left(X_{I} / X_{S}\right)=c t e-\eta \cdot \log \left(p_{I} / p_{S}\right)+a \cdot \log (Y C A P)+b \cdot \log ^{2}(Y C A P) \\
& \log \left(p_{I} X_{I} / p_{S} X_{S}\right)=c t e+(1-\eta) \cdot \log \left(p_{I} / p_{S}\right)+a \cdot \log (Y C A P)+b \cdot \log ^{2}(Y C A P)
\end{aligned}
$$

We expect to find that the relative value-added of industry at constant prices increases until a certain level of per capita income, which we call following RR the "turning point", before diminishing subsequently $(a>0, \quad b<0)$. Figures 1 and 2 illustrate the combined effects of decreasing relative price and economic development for value-added at constant and current prices respectively, according to (6a-b). 
At constant prices: before the turning point is reached, the share of industry in volume terms increases via the combination of the price effect (substitution) and the income effect. After the turning point, both effects oppose one another and the resultant is indeterminate.

At current prices and for employment: before the turning point, the demand effect opposes the loss of industrial employment linked to productivity gains, but it loses intensity over time. From the turning point onwards, the two effects operate in the same direction and deindustrialisation accelerates.

\section{$<<$ Figures 1 and 2 about here $>>$}

\section{DATA AND DESCRIPTIVE STATISTICS}

The data is mainly taken from the OECD STAN Database. "Industry" is restricted to manufacturing industries (ISIC 15 to 37), and "Services" is its complement in the economy. The trends we study would have been very similar, were the scope broadened to include the whole industry (with construction). The fixed capital formation series is real private fixed investment excluding stockbuilding from the OECD Economic O utlook. Trade variables are from the CHELEM-CEPII database. "D eveloped Countries" or "North" is composed of OECD countries except the CEECs, Turkey, South Korea and Mexico, whereas "D eveloping Countries" or "South" is the complement in total imports. Finally, real GDP per capita at purchasing power parity is in 1997 US dollar (source IMF).

We are interested here in the change in the share of manufacturing in employment between1970-2002 for the following countries: Austria, Belgium, Canada, Denmark, Spain, United States, Finland, France, United Kingdom, Italy, Japan, South Korea, Netherlands, Norway, Portugal and Sweden. German data are not available for the whole period and thus this country is excluded from the sample.

\section{The declining share of industry in total employment}

Let us first look at the declining share of industry in employment in Europe (Figure 3). This decline is widely observed, with three exceptions: Spain, Finland and Sweden. In the latter countries, the decline was stopped by the early '90s. All in all, manufacturing is occupying between $15 \%$ and $20 \%$ of the working force in the member states, to be compared with $30 \%$ on average in the early ' 60 s.

A similar outcome has been observed in other developed economies (Figure 4). This is the case in Japan, in the United States, and in Korea since the early '90s. In Canada, the decline was stopped in the early 
'90s. Accordingly, the view that deindustrialisation is a "natural" outcome in developed economies is at least partially confirmed: the phenomenon is recorded in various regions, for small as well as large countries, having reached the peak of their relative industrial employment at different periods, because of their different level of development. More interestingly, if one tries to date the phenomenon, we have very often to go back to the early '70s, or even to the '60s concerning the UK. In fact, six countries only (Finland, Italy, Japan, Korea, Portugal and Spain) have seen their manufacturing employment share peak between 1970 and 2002. Table 1 indicates that this peak was reached in a fairly narrow range of real GDP per capita $(\$ 10,000-\$ 14,000)$ except for Portugal, where it occurred at an earlier stage of development. Hence, the very forces of globalisation should not be interpreted, prima facie, as the engine of deindustrialisation of our economies. On the contrary, we observe that certain countries have stabilised the share of industry in total employment in the recent period characterised by the acceleration of globalisation.

\section{$<<$ Table 1 about here $>>$}

\section{The role of relative prices}

Since changes in relative prices are part of the explanation of the phenomenon at stake, we have to sort this out in order to observe the value added of industry at constant prices. This is done in Figure 3 for selected economies. The dotted line is the manufacturing share in total employment, the bold line the share of manufacturing in total value added (in GDP) and the grey line the latter share at constant 1980 prices. We observe that employment is tightly link to the value added at current prices, while the value added share at constant prices is rather stable. This confirms the mechanisms referred to above: larger productivity gains in the industry translate into a reduction in its share in total employment. But interestingly, when productivity gains are large, in the presence of increasing demand for manufactures, the share of industry in total output can increase (even at current prices), despite the decline of its share in total employment. Such outcome has been observed in Korea since the early 90s.

\section{$<<$ Figures 3, 4 and 5 about here $>>$}

We plot in Figure 6 the manufacturing share in total employment for two periods: 1970-1986 and 19862002. With the exception of Korea in the first period (where this country was in the process of rapid convergence) and a negligible increase in Italy in the second period, the magnitude of the effect is a 4 
percentage point change over each period on average (more precisely $-4.4 \%$ of total employment in the first period and $-3.9 \%$ in the second period). In percentage, the employment share lost on average $30 \%$ over the whole period, evenly spread over the two sub-periods when Korea is excluded. In total, one can hardly infer that deindustrialisation has accelerated recently.

\section{$<<$ Figure 6 about here $>>$}

On average, relative labour productivity of industry with respect to services increased at a pace of $1.6 \%$ annually, ranging from $-0.9 \%$ for Norway to $3.1 \%$ for Belgium. These productivity gains triggered an average decrease in the relative price of $1.25 \%$ on average, ranging from $+0.7 \%$ for Norway (the only country with an increase in the relative price), to $-2.3 \%$ for Korea and Japan. Figure 7 illustrates the linear correlation of $76 \%$ between the two series (significant at $1 \%$ ).

Lastly, we have to take into account the potential impact of the competition from the South on those evolutions. The kind of mechanism referred to above is portrayed in Figure 8. Since the first oil shock, as shown in the left hand panel, France has been facing a combination of declining relative production and employment largely explained by the strong decline in relative prices: hence the suspect is definitively productivity gains. However, the right hand panel in which imports from emerging economies are plotted points to at least a coincidence of movements of relative prices and those imports. Accordingly, the decline in relative prices through the induced productivity gains might be at least partially explained by the competition from the South. Such evidence would fit the hypothesis of defensive innovation referred to above. The cross-country linear correlation coefficient between relative (industry vs services) productivity gains and the increase in manufacturing import ratios from developing countries between 1970 and 2002 is positive (56\%) and significant at 3\% level. In order to sort out these effects, an econometric exercise will authorise to go beyond partial and bivariate evidence.

\section{$<<$ Figure 8 about here $>>$}




\section{ECONOMETRIC SPECIFICATION AND RESULTS}

\section{Econometric specification}

The different mechanisms referred to in Section 3 can now be taken into account. Based on equation (6a), the determinants of the relative (industry vs services) output in volume, RE L OU TPUT, should include the development level Y CA P (income per capita) and the relative price, RE L PR ICE . Also, insofar as capital investment increases the relative demand for manufactured products, fixed capital formation as a percentage of real GDP, FIX CA P, should also be included. Finally, trade variables appear on the RHS.

$$
\text { RE L OUTPUT }=h(Y \text { CA P, Y CA P2, RE L PRICE, TRA DE, FIX CA P) }
$$

In addition, trade has an indirect impact, channelling through the relative price. The latter is supposed to depend also on exogenous relative TFP growth. To capture the total effect of trade, as relative employment is the difference between relative output and relative labour productivity (all these variables expressed in logarithm), the manufacturing share in total employment, E M PSH A RE , is, in the reducedform equation, of the following type:

$$
\text { E MPSH A RE }=f(Y \text { CA P, Y CA P² }, \text { TRA DE, FIX CA P, ex ogenous TFP })
$$

As for the impact of international trade in manufactured products, the effect of imports from developing countries should be taken into account separately. Indeed and following Wood (1994), the labour content of trade, expressed as a percentage of GDP, is most likely larger if this given percentage comes from a developing country rather than a developed one. This comes from differences in both capital/ labour intensity and labour costs. IM PSO UTH is defined as the imports from developing countries and BA LA N CE is the trade balance, both expressed as a share of GDP.

\section{Results}

Let us start with the relative output share (at constant prices). All estimates in Table 2 include country fixed effects and are in line with those of RR. In the first column, real income and relative price only are taken into account. At constant relative price, manufacturing share in real output starts by increasing and reaches a turning point at around $\$ 10,000$ for the GDP per capita, which corresponds to the level of development reached by the most developed countries in the early '60s. Moreover, RR got an elasticity of -0.59 to the relative price, similar to our -0.62 . To the extent that this relative price is exogenous, this 
$60 \%$ parameter could be interpreted as the elasticity of substitution between manufactured products and services in the demand function, at constant income. Therefore, the OLS estimates are consistent with a fairly slow (relatively high elasticity of substitution) deindustrialisation, being somehow accelerated by a wealth effect materialising some forty years ago for the most developed countries. However, ignoring supply effects means that this elasticity is biased downwards.

In the second column, we introduce imports from developing economies, overall trade balance and the ratio of capital formation over GDP. The "elasticity of substitution" is then estimated lower at -0.49 . The investment variable is significant and has the expected positive sign. In addition, the trade variables have some explanatory power and an increase in the trade balance of 1 point of GDP (which is roughly 5 points of manufacturing value-added) is associated with an increase of $1.8 \%$ in the relative real valueadded. Note that this applies for all trade, except imports from the South which do not appear to have any impact overall.

\section{$<<$ Table 2 about here $>>$}

Importantly, in addition to endogeneity issues, OLS residuals are poised with auto-correlation and since the series is very likely persistent, a dynamic specification must be preferred. Therefore, estimates based on the G MM methodology for dynamic panels developed by Arellano and Bond (1991) are presented next, for the main focus of this study, the manufacturing employment share (defined as manufacturing over total employment).

In order to control for exogenous TFP, the reduced-form specification must include time dummies. Results are presented in Table 3. The first column reports the OLS estimates in the static specification case, for the sake of comparison. Column 2 and 3 refer to the GMM estimates, using the second to fourth lags of the dependent and trade variables as instruments, for the partial adjustment model and a more complete dynamic specification, respectively. The serial correlation and overidentification tests reject neither the specification nor the validity of the instruments. However, the significance of the lagged variable parameters and second-order serial correlation clearly support the more complete specification in column 3, our benchmark estimates. Moreover, column 4 presents the estimates using the third to fifth lag of the trade variables as instruments.

\section{$<$ Table 3 about here $>>$}


To get a more readable picture of the results, Table 4 gives the long-term sensitivities of the employment share to the explanatory variables. 5 The expected sign of the impacts of income per capita are recorded in all estimates. However, the turning point is somewhat lower than expected from table $1 .{ }^{6}$ The significant impact of investment does not resist to the dynamic specification and turns even negative in the more complete setting.

Let us now focus on the trade variables. As explained in the preceding section, the impact of trade might operate through both the volume output (as shown in table 2) and the relative productivity. From column 3, we infer that an increase in the imports from the South of 1 point of GDP reduces the manufacturing employment share by $4.0 \%$ in the long term, whereas that number is $1.1 \%$ only if imports come from the North. This fairly high ratio of 3.5 gives an order of magnitude for the labour content of imports from South relative to that from North for a given dollar value.

We also tested whether the impact of imports from developing countries, as measured by the IM PSOUTH parameter, was more pronounced in the second half of the period (1986-2002), and could not find any significant difference between the two sub-periods.

\section{How do these results compare with RR's?}

RR limit their approach to the static specification. In their Table 4, they present estimates with and without time dummies, directly comparable to our own Table 4 . The turning point and the impact of the trade balance are very closely estimated. However, there are two main differences. In their specification without time dummies, the IM PSO U TH parameter is greater in absolute terms than our 2.85 but not significantly different. In the one with time dummies, which as we argued ought to be preferred to account for exogenous TFP, their estimate seems large at 6.7, leading to a "South/ North" ratio of 6.6.

Secondly, in both their specifications, they obtain a much higher sensitivity of the manufacturing employment share to income per capita. When time dummies are included, this sensitivity might be interpreted as the elasticity of manufacturing employment to income. In this case with a similar turning point, this elasticity varies in a range of $(0.25,-0.50)$ when GDP per capita increases from $\$ 5,000$ to $\$ 30,000$ in our case, whereas from $R R$ estimates, this range is $(0.80,-1.40)$. 
Finally, our results being close to RR's overall, the dynamic specification and the treatment of trade endogeneity, with the usual reservations due to the low power of the overidentification tests, reinforce the confidence one could place in these numbers.

\section{Contributions to deindustrialisation}

Based on our benchmark estimates in column 3, Table 5 gives the changes in the manufacturing employment share induced by the changes in explanatory variables, as well as the total contribution of trade with developing economies. The contribution of trade with low wage economies would explain $20 \%$ on average of the observed decline in the manufacturing employment share.7 The magnitude of such effect varies from 7\% only in Sweden, notwithstanding the remarkable internationalisation of Swedish firms, to more than a third in Italy, Austria and Finland, where it is to be remembered that the total decrease in the employment share is much lower than the average. The contribution for Korea cannot be interpreted for obvious reasons.

Stated differently, trade with developing countries is associated with an average decrease of 1.9 points in the employment share, varying from 0.7 points for Korea and Sweden to 4.3 points for the Netherlands. One could calculate what would be manufacturing employment in 2002, if the countries had maintained their trade ratios with developing countries at the 1970 level. For the USA, Japan and France, for example, this means that, given the total employment in 2002 of 134.3, 65.4 and 24.9 million respectively, one can assess that trade with developing countries "costs" around 3.3 million, 1.4 million and 350000 manufacturing jobs respectively, part of which being compensated by jobs in the service sector. ${ }^{8}$

\section{$<$ T ables 4 and 5 about here $>>$}

Interestingly, one can also calculate such a contribution for the two sub-periods we have defined, namely before and after 1986. Doing so, we can identify the expected acceleration of the phenomenon: it is simply twice as large in the second sub-period. 
The following conclusions can be drawn based on this econometric exercise:

- First, net trade with low wage countries is associated with a non-negligible decrease of around 2 points in the manufacturing employment share between 1970 and 2002, on average across countries.

- Second, this represents, on average, only a fifth of the deindustrialisation over the period, i.e. of the average drop of 8.3 points in the manufacturing employment share, despite the acceleration of the phenomenon during the second half of our period. However, this contribution varies a lot across countries, in a range of one to five.

- Third, not all trade flows with countries of offshoring are associated with offshoring: some "autonomous" trade flows take place just because emerging economies are specialising and trading with our rich economies. Accordingly, the average $20 \%$ contribution is a pessimistic view.

\section{Conclusion}

The decline in the share of industry in total employment, the so-called deindustrialisation, currently seems to be accelerated by the forces of globalisation. Civil society has come to fear a systematic relocation of manufacturing activities towards low wage economies. Such a process is being favoured by the ongoing international fragmentation of production, which makes more appealing to combine the comparative advantages of the various locations available.

In order to address these fears, we tentatively measure the impact of trade with low wage countries hosting offshore-outsourced activities on the observed deindustrialisation in sixteen OECD economies. We use panel data covering the 1970-2002 period in order to estimate the respective contributions of income per capita, investment and net trade with low wage countries offering these new appealing locations.

We find that trade in goods with developing countries accounts, at most, for a third of deindustrialisation, and for only a fifth on average in our sample. It appears that the best way to slow or even reverse the decline of the industry is by increasing productivity in services. 


\section{REFERENCES}

Amiti M., Wei S.J. 2004. Fear of Service O utsourcing: is it Justified?, N BE R W orking Paper, no. 10808.

Anderton, R., Brenton, P. 1999. O utsourcing and low-skilled workers in the UK, Bulletin of E conomic Research, vol. 51, no. 3: 1-19.

Arellano M., Bond S. 1991. Some Tests of Specification for Panel D ata: Monte Carlo Evidence and an Application to Employment Equations. Review of E onomic Studies, vol. 58 : 277-297.

Arthuis J. 1993. Rapport du Sénat sur l'incidence éonomique et fiscale des délocalisations hors du territoire national des adivités industrielles et de servios, no. 337.

Aw B.Y., Roberts M.J. 1985. The Role of Imports from the Newly Industrializing Countries in US Production, Review of E conomics and Statistics , vol. 67, no. 1.

Barba-Navaretti G., Castellani D. 2003. Investments Abroad and Performance at Home. Evidence from Italian Multinationals, C entro Studi L uca d'A gliano D evelopment Studies W ork ing Papers, no. 180.

Bhagwati J., Panagariya J. \& Srinivasan T.N. 2004. The Muddles over O utsourcing, Journal of E conomic Perspectives, vol. 18, no. 3.

Chen T.J., Ku Y.H. 2003. The Effect of Overseas Investment on D omestic Employment, N BE R W orking Paper:, no. 10156.

Feenstra, R. C., Hanson G.H. 1996. Globalization, O utsourcing, and Wage Inequality, A merican E conomic Review, vol. 86, no. 2 : 240-45.

Fontagné L., Freudenberg M., Ünal-Kezenci D. 1996. Statistical Analysis of EC Trade in Intermediate Products, Eurostat, Série 6D, March.

Hanson, G. H., Mataloni R. J., Slaughter M. J. 2003. Vertical Production Networks in Multinational Firms, N BE R W orking Papers, no. 9723.

Hijzen A. 2003. Fragmentation, Productivity and Relative Wages in the UK: A Mandated Wage Approach, G E P Research Paper, no. 03/ 17, University of Nottingham.

Hijzen A., Görg H., Hine R.C. 2003. Intemational Fragmentation and Relative Wages in the UK, IZA D isaussion Paper, no. 717. 
Hine R.C., Wright P.W. 1998., Trade with Low Wage Economies, Employment and Productivity in UK Manufacturing, The E conomic Journal, vol. 108, no. 450:1500-1510.

Hummels D., Ishii J ., Y I K. M. 2001., The Nature and Growth of Vertical Specialization in World Trade, Journal of International E conomics, vol. 54, no. 1: 75-96.

Kirkegaard J.F. 2004. O utsourcing - Stains on the White Collar ?, Institute for International E onomics working document.

Krugman P. 1996. D omestic Distortions and the D eindustrialization Hypothesis. In The political economy of trade policy: in honour of Jagdish Bhagwati: 33-49, Cambridge and London: MIT Press.

Mann C. 2003. Globalization of IT Services and White Collar Jobs: The Next Wave of Productivity Growth, International E conomics Policy Briefs, PB03-11, Institute for International Economics, Washington DC.

Marin D. 2004. A Nation of Poets and Thinkers. Less so with Eastern Enlargement? Austria and Germany. CE PR D isaussion paper, no. 4358.

Roodman D. 2003. XTABOND2: Stata module to extend xtabond dynamic panel data estimator. Statistical Software Components S435901, Boston College Department of Economics.

Rowthorn R.E., Coutts K. 2004. D e-industrialisation and the Balance of Payments in Advanced Economics, Cambridge Journal of E conomics, vol. 28, no. 5: 767-790.

Rowthorn R.E., Ramaswamy 1997. D eindustrialization- Its Causes and Implications, IM F E conomic issues, no. 10.

Rowthom R.E., Ramaswamy R. 1998. Growth, Trade an D eindustrialization, IM F work ing paper, WP/ 98/ 60.

Sachs J.D ., Shatz H.J. 1994. Trade and Jobs in U.S. Manufacturing, Brooking Papers on E conomic A ctivity, vol. 94, no. 1: 1-84.

Samuelson P.A. 2004. Where Ricardo and Mill Rebut and Confirm Arguments of Mainstream Economists Supporting Globalization , Journal of E conomic Perspectives, vol. 18, no. 3 : 135-146.

Sanyal K. K. 1983. Vertical Specialization in a Ricardian Model with a Continuum of Stages of Production, E onomica, vol. 50, 197 
Sanyal K. K., Jones R. W. 1982. The Theory of Trade in Middle Products, A merican E conomic Review, vol. 72, no. 1.

Strauss-Kahn V. 2003. The Role of Glo balization in the Within-Industry Shift Away from Unskilled Workers in France, N BE R W orking Papers, no. 9716.

Thoenig M., Verdier T. 2002. A Theory of D efensive Skill-Biased Innovation and Globalization, CE PR D iscussion paper , no. 3416.

United States Government Accountability O ffice 2004. Current Government Data Provide Limited Insight into Offshoring of Services, Report to C ongressional Requesters, GAO 04-932.

van Welsum, D . 2004. Potential O ffshoring of ICT-Intensive Using O ccupations, Working Party on the Information Eco.

Wood A. 2004. N orth-South Trade, E mployment and Inequality, Oxford Clarenton Press.

\section{Footnotes}

${ }^{1}$ In that sense, our results complement the recent update provided by Rowthorn and Counts (2004).

${ }^{2}$ US D epartment of Commerce (2004).

3K rugman (1996) p.5.

4 Obviously, this is a restrictive framework because the reasoning is conducted at a fixed scope. In practice, because of innovation, new sectors are emerging, benefiting from both high productivity and sustained demand.

Furthermore, intern ational trade represents a leverage effect for the countries that manage to specialise in these vibrant sectors (and viœ versa for the other).

5For example, the long-term sensitivity to imports from developing countries of -2.848 in column 3 is defined as the sum of 0.215 and -0.641 divided by 1 minus the sum of the lagged employment share parameters 1.009 and -0.159 . ${ }^{6}$ Note that, based on the cumulative impact of the two curves in Figure 2, the employment share should peak before the turning point.

The average contribution is a weighted average using the absolute change in the employment share as weight. The unweighted average is slightly less than two points higher. When Korea, the only country for which the employment share has increased over the period, is excluded, the weighted average contribution increases from $19.8 \%$ to $21.2 \%$. 8In the United States, the changes in trade with developing countries between 1970 and 2002 is associated with a 2.5 point loss in the manufacturing employment share and 2.5\%*134.6 million=3.3 million. 


\section{Tables and Figures}

Figure 1: Price and wealth effects on relative output (volume)

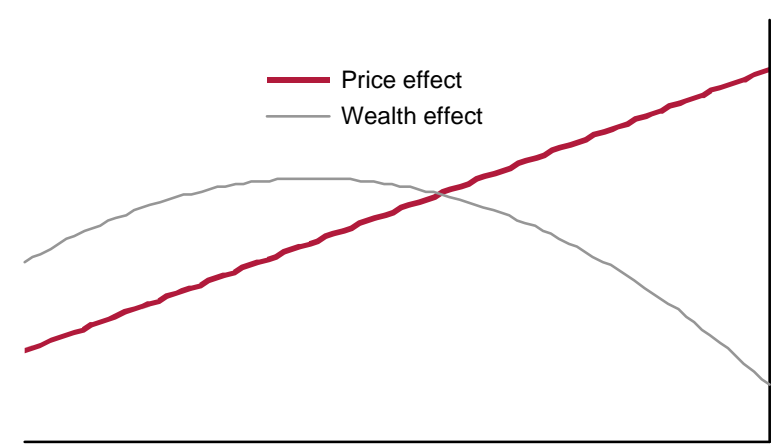

Time
Figure 2: Price and wealth effects on relative value output and employment

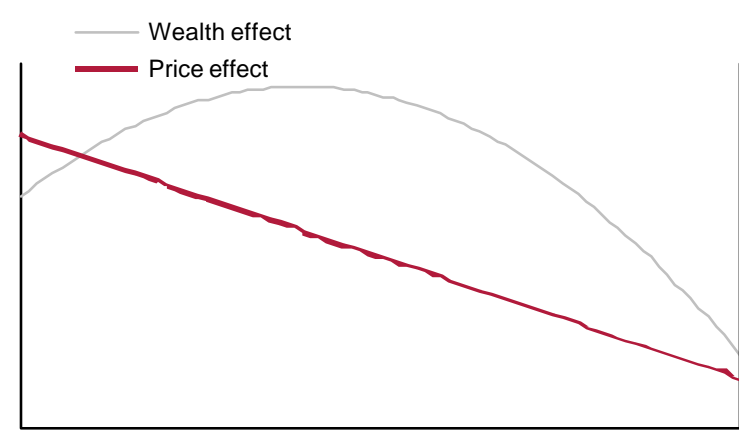

Time 
Figure 3: Manufacturing Share in Employment in Selected Member States (1970-2002)

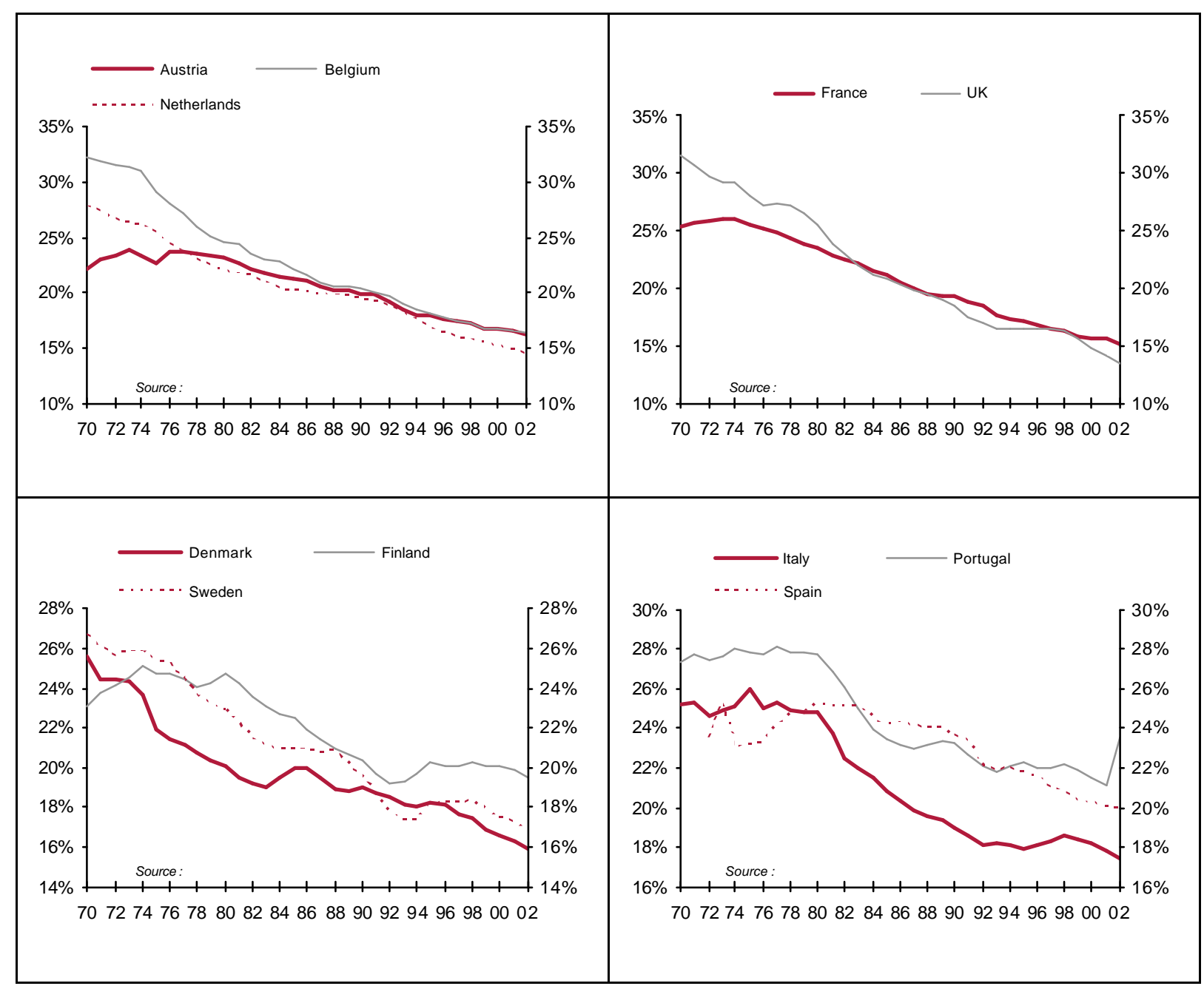

Sourœe: OE CD , STA N 
Figure 4: Manufacturing Share in Employment in O ther Developed Countries (1970-2002)

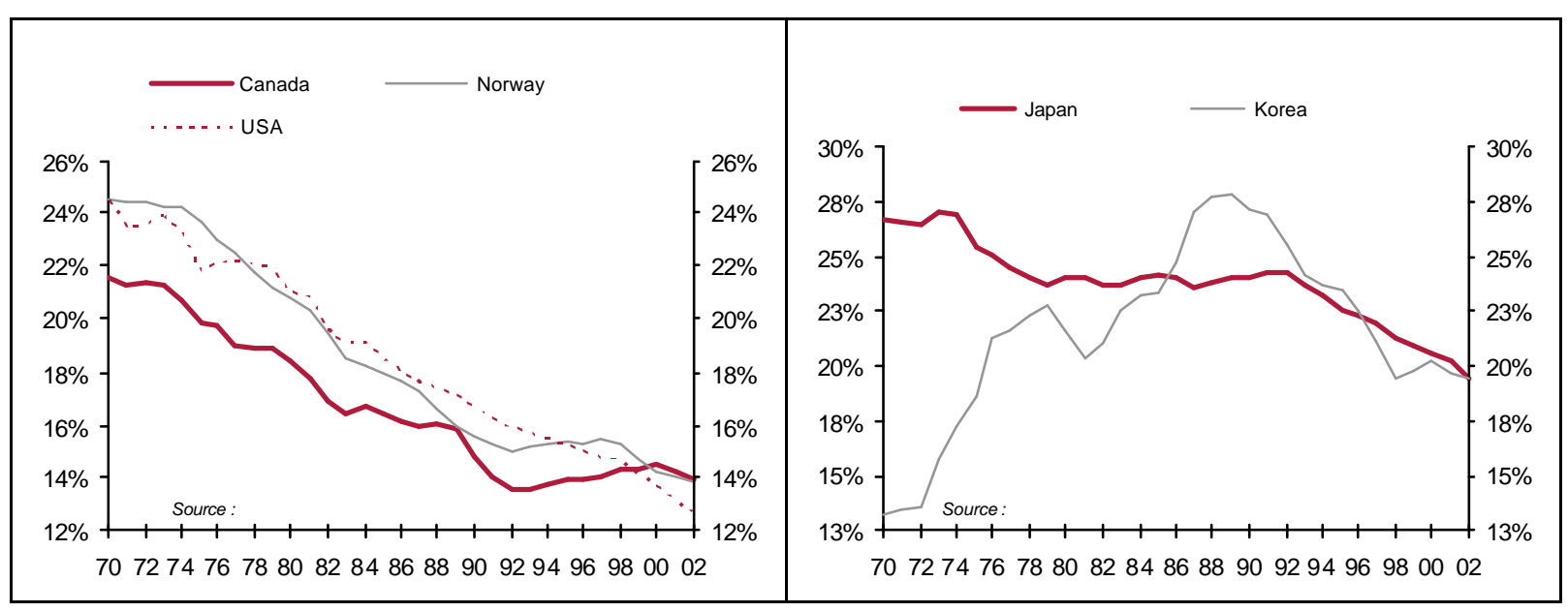

Sourœ: OE CD, STA N 
Figure 5: Manufacturing Share in E mployment, Value Added at Current and Constant Prices in

\section{Selected Countries (1970-2002)}

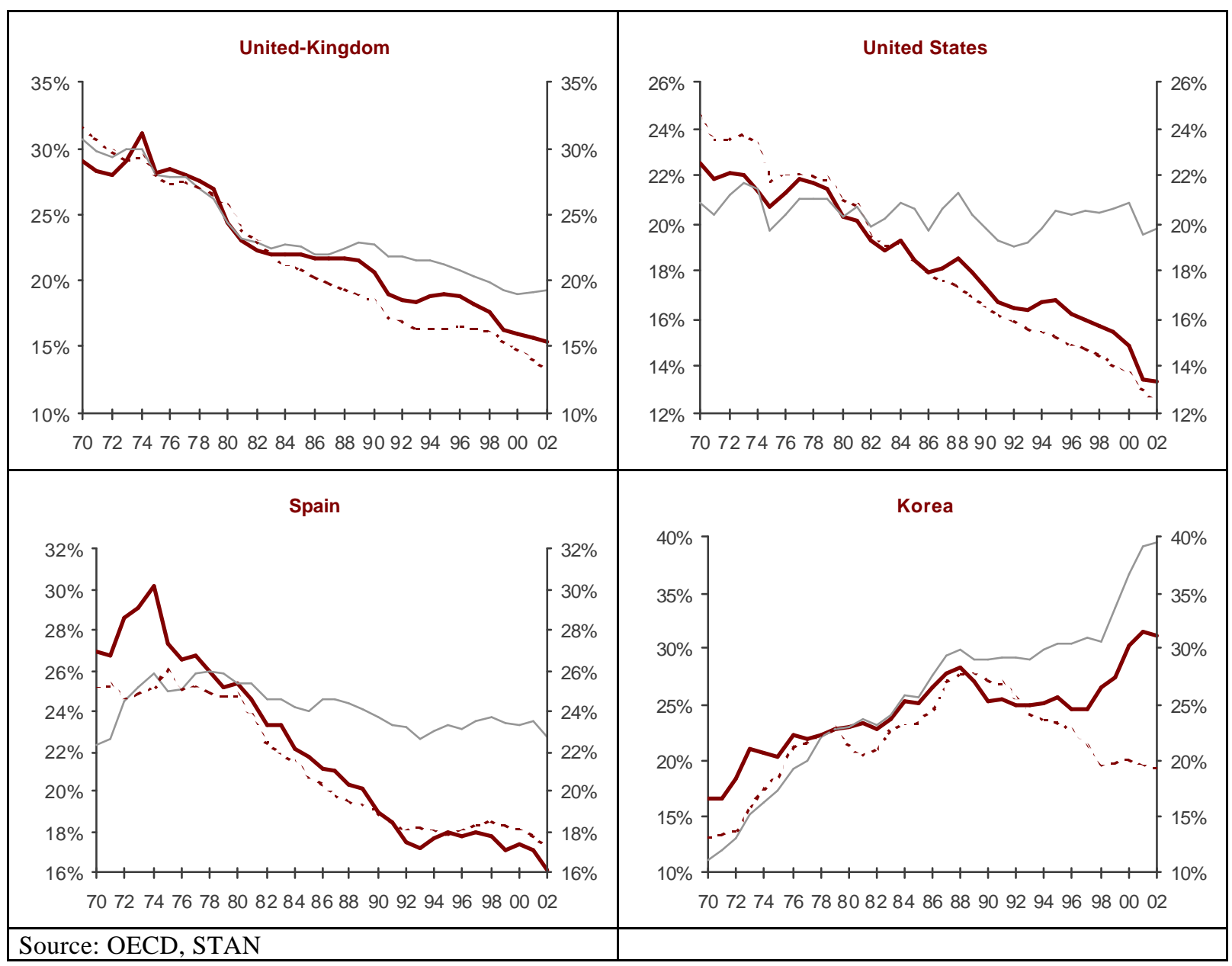


Figure 6: Percentage Change in the Share of Manufacturing in Employment, 1970-1986 and 19862002

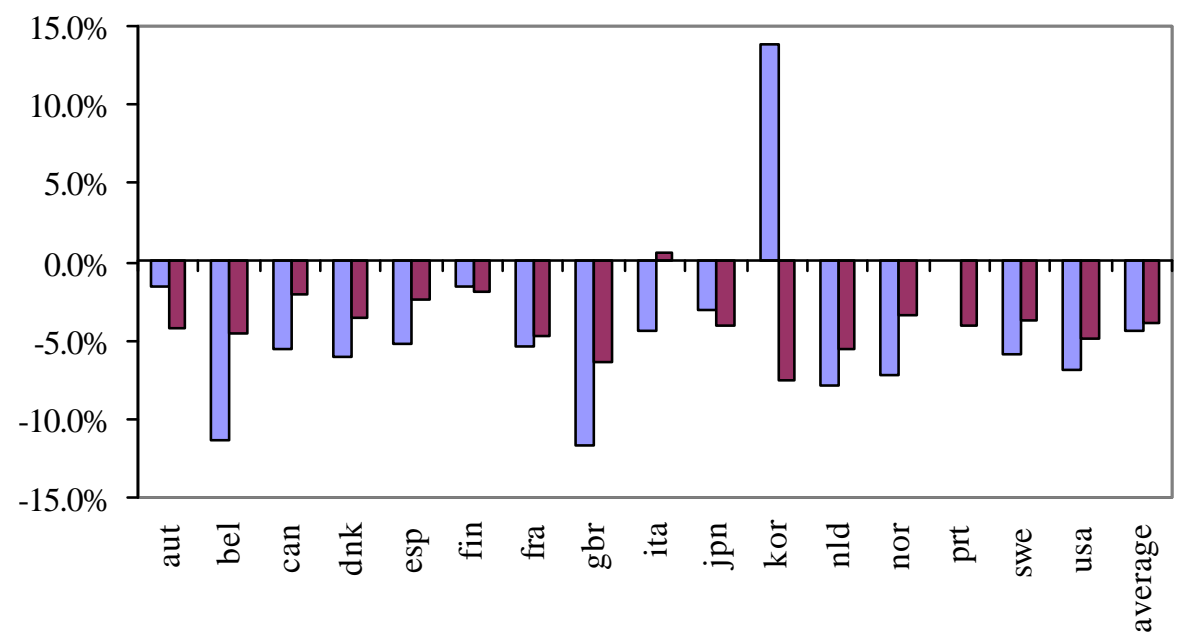

Source: OECD, Stan, author's calculations 
Figure 7: Comelation between relative (industry vs services) price and productivity changes between 1970 and 2002

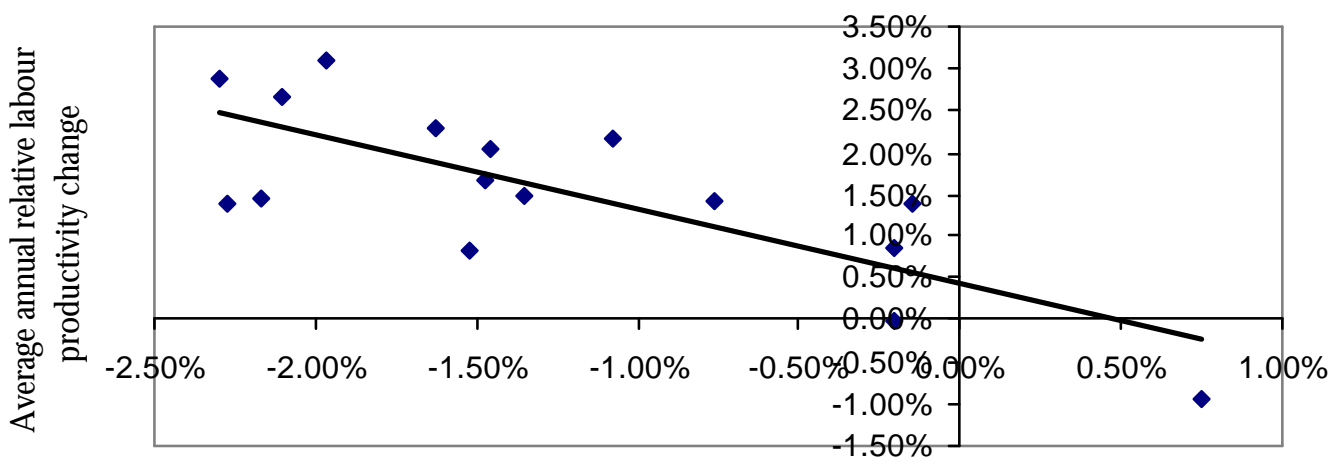

E ach diamond shape represents a country

Average annual relative price change 
Figure 8: Relative (Manufacturing vs Services) Employment, Production and Prices (left scale), and Imports from Developing Economies (share of GDP, right scale): France, 1970-2002

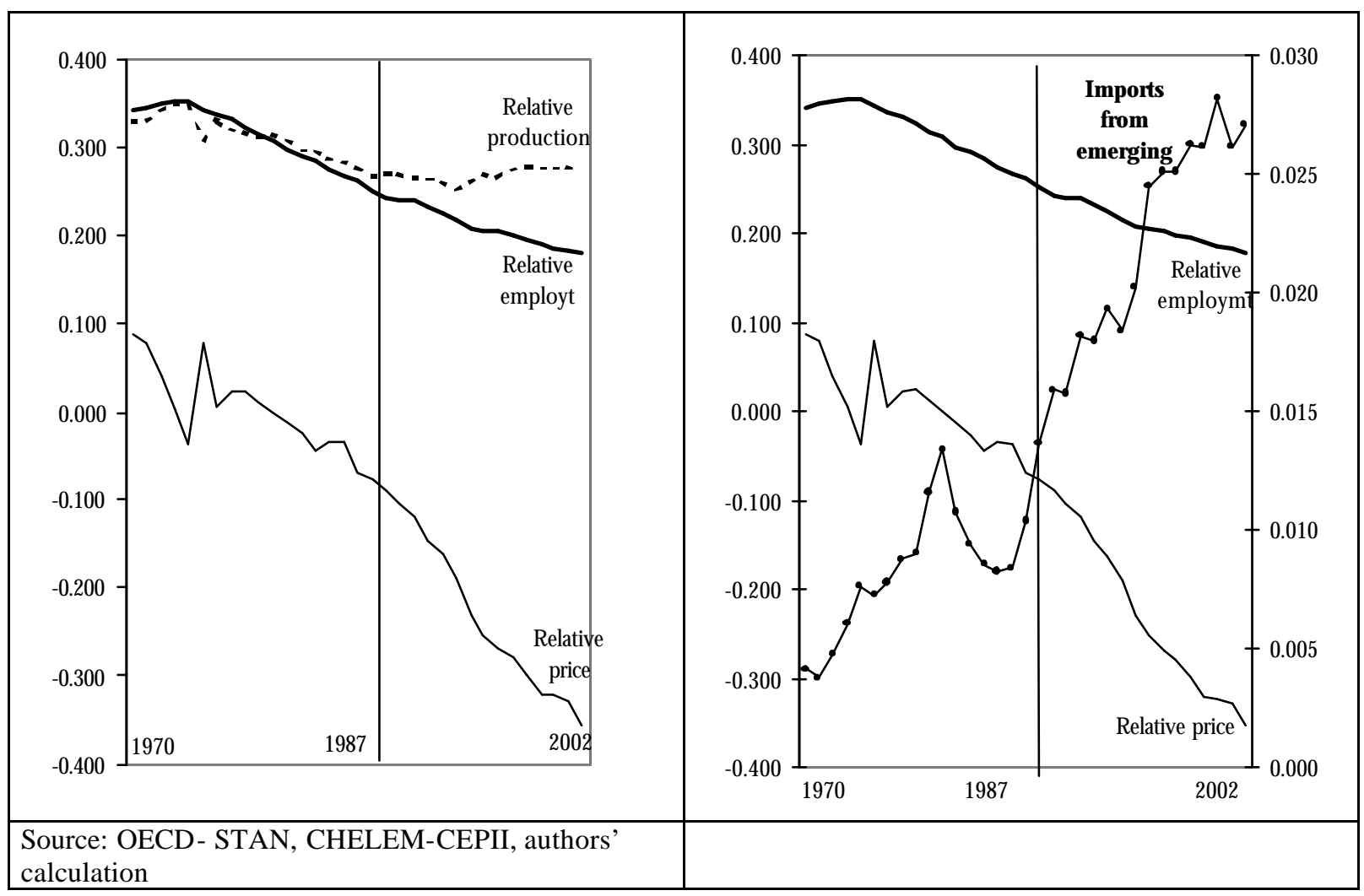




\section{Table 1}

Peak of the Manufacturing Employment Share, 1970-2002

\begin{tabular}{l|c|c|c} 
& & & $\begin{array}{c}\text { GD P per } \\
\text { capita (1997 } \\
\text { PPP US } \\
\text { dollar) }\end{array}$ \\
\hline Spain & Year & Share & 10741 \\
Finland & 1974 & $25.1 \%$ & 13008 \\
Italy & 1977 & $28.1 \%$ & 13862 \\
Japan & 1973 & $27.0 \%$ & 13120 \\
Korea & 1989 & $27.8 \%$ & 9357 \\
Portugal & 1973 & $25.4 \%$ & 7591 \\
\hline Average & & $26.5 \%$ & 11280
\end{tabular}


Table 2

\section{Dependent variable: Log (Relative Share of Manufacturing vs Senvices}

\section{in Value Added at Constant Prices)}

\begin{tabular}{l|c|c} 
& OLS & OLS \\
\hline YCAP & 9.07 & 7.8 \\
& $(0.399)$ & $(0.506)$ \\
YCAP $^{2}$ & -0.491 & -0.427 \\
& $(0.021)$ & $(0.027)$ \\
RELPRICE & -0.619 & -0.493 \\
& $(0.046)$ & $(0.044)$ \\
IMPSO UTH & & 2.01 \\
& & $(0.83)$ \\
BALANCE & & 1.817 \\
& & $(0.2)$ \\
FIX CAP & & 0.176 \\
& & $(0.036)$ \\
country fixed effects & yes & yes \\
turning point (\$PPA) & 10263 & 9260 \\
\hline
\end{tabular}

$\mathrm{N}$ otes

YCAP is the log of real GDP per capita. RE L PRICE is the log of the relative price of manufactures vs services. IMPSOUTH is the share of manufacture imports from developing countries in GDP, BA LA NCE is the manufacture trade balance and FIX CA P is log of fixed capital formation, both as a percentage of GD P. 
Table 3

Dependent variable: EMPSHARE = Log (Manufacturing Share in Total Employment)

\begin{tabular}{|c|c|c|c|c|}
\hline & $\begin{array}{l}\text { Level } \\
\text { OLS } \\
\text { (1) }\end{array}$ & $\begin{array}{c}\text { First- } \\
\text { differences } \\
\text { GMM } \\
(2)\end{array}$ & $\begin{array}{c}\begin{array}{c}\text { First- } \\
\text { differences }\end{array} \\
\text { GMM } \\
\text { (3) }\end{array}$ & $\begin{array}{c}\begin{array}{c}\text { First- } \\
\text { differenœes }\end{array} \\
\text { G MM } \\
\text { (4) }\end{array}$ \\
\hline $\begin{array}{l}\text { Lag EMPSHARE } \\
\text { Lag2 EMPSHARE }\end{array}$ & & $\begin{array}{c}0.850^{* * *} \\
(0.034)\end{array}$ & $\begin{array}{c}1.009 * * * \\
(0.073) \\
-0.159 * *\end{array}$ & $\begin{array}{c}0.998^{* * *} \\
(0.070) \\
-0.148^{*}\end{array}$ \\
\hline $\begin{array}{l}\text { YCAP } \\
\text { Lag YCAP }\end{array}$ & $\begin{array}{c}4.521^{* * *} \\
(0.420)\end{array}$ & $\begin{array}{c}0.271 \\
(0.580)\end{array}$ & $\begin{array}{c}(0.069) \\
3.022 \\
(2.678) \\
-5.301 * *\end{array}$ & $\begin{array}{c}(0.07) \\
3.072 \\
(2.757) \\
-5.264 * *\end{array}$ \\
\hline Lag2 Y CAP & & & $\begin{array}{l}(1.893) \\
2.864^{* *}\end{array}$ & $\begin{array}{l}(1.915) \\
2.831^{* *}\end{array}$ \\
\hline $\begin{array}{l}\mathrm{YCAP}^{2} \\
\text { Lag YCAP }^{2}\end{array}$ & $\begin{array}{c}-0.23^{* * *} \\
(0.024)\end{array}$ & $\begin{array}{l}-0.016 \\
(0.033)\end{array}$ & $\begin{array}{l}-0.142 \\
(0.135) \\
0.268^{* *}\end{array}$ & $\begin{array}{l}-0.144 \\
(0.140) \\
0.265^{* *}\end{array}$ \\
\hline Lag2 YCAP ${ }^{2}$ & & & $\begin{array}{c}(0.096) \\
-0.159 * *\end{array}$ & $\begin{array}{c}(0.097) \\
-0.157 * *\end{array}$ \\
\hline $\begin{array}{l}\text { IMPSO UTH } \\
\text { Lag IMPSO UTH }\end{array}$ & $\begin{array}{c}-1.847^{* * *} \\
(0.600)\end{array}$ & $\begin{array}{l}-0.403 \\
(0.305)\end{array}$ & $\begin{array}{c}0.215 \\
(0.229) \\
-0.641 * *\end{array}$ & $\begin{array}{c}0.375 \\
(0.299) \\
-0.658^{* *}\end{array}$ \\
\hline BALANCE & $0.983^{* * *}$ & $0.137 *$ & $\begin{array}{l}(0.263) \\
0.242^{* *}\end{array}$ & $\begin{array}{c}(0.297) \\
0.197 *\end{array}$ \\
\hline Lag BALANCE & $(0.129)$ & $(0.076)$ & $\begin{array}{l}(0.102) \\
-0.076\end{array}$ & $\begin{array}{l}(0.095) \\
-0.114\end{array}$ \\
\hline FIXCAP & $0.058 * *$ & 0.031 & $\begin{array}{c}(0.081) \\
0.035\end{array}$ & $\begin{array}{c}(0.088) \\
0.03\end{array}$ \\
\hline Lag FIXCAP & $(0.024)$ & $(0.019)$ & $\begin{array}{l}(0.027) \\
-0.044\end{array}$ & $\begin{array}{l}(0.026) \\
-0.042\end{array}$ \\
\hline $\begin{array}{l}\text { country dummies } \\
\text { time dummies }\end{array}$ & $\begin{array}{l}\text { yes } \\
\text { yes }\end{array}$ & yes & $\begin{array}{c}(0.027) \\
\text { yes }\end{array}$ & $\begin{array}{c}(0.026) \\
\text { yes }\end{array}$ \\
\hline $\begin{array}{l}\text { First-order serial correlation } \\
\text { Second-order serial œrrelation } \\
\text { Sargan-Hansen overid. test }\end{array}$ & & $\begin{array}{l}0.017 \\
0.120 \\
1.000 \\
\end{array}$ & $\begin{array}{l}0.003 \\
0.851 \\
1.000 \\
\end{array}$ & $\begin{array}{l}0.004 \\
0.800 \\
1.000\end{array}$ \\
\hline
\end{tabular}

(i) Variables are described in Table 2.

(ii) GMM is the one-step Arellano-Bond estimator, using as instruments the second to fourth lags of the dependent variable in block diagonal form and the second to fourth lags of trade variables in columns 2 and 3, and the third to fifth lags of the trade variables in column 4.

(iii) Asymptotic standard errors, between parentheses, are robust to heteroscedasticity and autocorrelation and computed from Roodman (2003). *, ** and *** indicate significance at 90\%, 95\% and 99\% confidence level, respectively.

(iv) For the Sargan-Hansen test, the number reported is the confidence level at which the overidentifying restrictions can be rejected.

(v) Serial correlation statistics are P-values for Arellano-Bond tests for first- and second-order correlation. 


\section{Table 4}

Long-term Sensitivities based on table 3

Dependent variable: Log (Manufacturing Employment Share)

\begin{tabular}{l|c|c|c|c} 
& Level & $\begin{array}{c}\text { First- } \\
\text { differences }\end{array}$ & $\begin{array}{c}\text { First- } \\
\text { differences }\end{array}$ & $\begin{array}{c}\text { First- } \\
\text { differences }\end{array}$ \\
& OLS & GMM & GMM & G MM \\
& $(1)$ & $(2)$ & $\mathbf{( 3 )}$ & $(4)$ \\
\hline YCAP & 4.521 & 1.808 & $\mathbf{3 . 9 2 6}$ & 4.285 \\
YCAP2 & -0.229 & -0.104 & $\mathbf{- 0 . 2 1 6}$ & -0.237 \\
IMPSOUTH & -1.846 & -2.682 & $\mathbf{- 2 . 8 4 8}$ & -1.884 \\
BALANCE & 0.983 & 0.915 & $\mathbf{1 . 1 1 8}$ & 0.559 \\
FIXCAP & 0.059 & 0.205 & $\mathbf{- 0 . 0 5 8}$ & -0.069 \\
& 19202 & 6220 & $\mathbf{8} \mathbf{6 9 0}$ & 8550 \\
turning point (1997 \$, PPP) & 192.9 & 3.9 & $\mathbf{3 . 5}$ & 4.4 \\
D eveloping / Developed & 2.9 & & & \\
\hline
\end{tabular}


Table 5

Changes in the Manufacturing Employment Share Induced by the Changes in Explanatory

Variables and Total Contribution of Trade with Developing Economies (in \% of total change)

G MM estimates from olumn 3 of table 4

\begin{tabular}{c|c|c|c|c|c|c|c|c} 
Country & $\begin{array}{c}\text { Change in } \\
\text { the } \\
\text { employment } \\
\text { share }\end{array}$ & Investment & $\begin{array}{c}\text { Income per } \\
\text { capita }\end{array}$ & $\begin{array}{c}\text { Manufact. } \\
\text { trade } \\
\text { balance }\end{array}$ & $\begin{array}{c}\text { Imports } \\
\text { from } \\
\text { developing }\end{array}$ & $\begin{array}{c}\text { Exports to } \\
\text { developing }\end{array}$ & $\begin{array}{c}\text { Residuals + } \\
\text { exogenous } \\
\text { TFP }\end{array}$ & $\begin{array}{c}\text { Contrib. } \\
\text { of } \text { trade }^{\text {tradh }} \\
\text { with } \\
\text { developing }\end{array}$ \\
\hline Italy & $\mathbf{- 3 . 8}$ & 0.3 & -4.5 & 0.2 & -2.2 & 0.8 & 1.6 & $\mathbf{3 6 . 8}$ \\
Austria & $\mathbf{- 5 . 8}$ & -0.1 & -4 & 0.1 & -2.9 & 0.8 & 0.3 & $\mathbf{3 6 . 2}$ \\
Finland & $\mathbf{- 3 . 5}$ & 0.6 & -4 & 1.8 & -2.4 & 1.2 & -0.7 & $\mathbf{3 4 . 3}$ \\
Netherl. & $\mathbf{- 1 3 . 4}$ & 0.3 & -4 & 0.4 & -4.7 & 0.4 & -5.8 & $\mathbf{3 2 . 1}$ \\
Portugal & $\mathbf{- 3 . 5}$ & 0.1 & -0.9 & -0.2 & -1.1 & 0 & -1.4 & $\mathbf{3 1 . 4}$ \\
Japan & $\mathbf{- 7 . 1}$ & 0.1 & -4.7 & 0.3 & -2.9 & 0.8 & -0.7 & $\mathbf{2 9 . 6}$ \\
Canada & $\mathbf{- 7 . 6}$ & -0.3 & -3.9 & 0.4 & -2.1 & 0 & -1.7 & $\mathbf{2 7 . 6}$ \\
USA & $\mathbf{- 1 1 . 8}$ & -0.3 & -5 & -0.2 & -2.7 & 0.2 & -3.8 & $\mathbf{2 1 . 2}$ \\
Belgium & $\mathbf{- 1 5 . 9}$ & 0 & -4.6 & 1.3 & -4.6 & 1.4 & -9.4 & $\mathbf{2 0 . 1}$ \\
Denmark & $\mathbf{- 9 . 6}$ & -0.1 & -4 & 1.1 & -2.4 & 0.5 & -4.7 & $\mathbf{1 9 . 8}$ \\
Spain & $\mathbf{- 7 . 7}$ & 0 & -2.6 & -0.3 & -1.9 & 0.4 & -3.3 & $\mathbf{1 9 . 5}$ \\
Norway & $\mathbf{- 1 0 . 6}$ & 0.5 & -5.7 & -0.7 & -1.6 & -0.1 & -3 & $\mathbf{1 6 . 0}$ \\
France & $\mathbf{- 1 0 . 3}$ & 0 & -3.9 & 0 & -1.8 & 0.4 & -5 & $\mathbf{1 3 . 6}$ \\
UK & $\mathbf{- 1 8 . 1}$ & -0.2 & -4.3 & -0.6 & -2.2 & 0 & -10.8 & $\mathbf{1 2 . 2}$ \\
Sweden & $\mathbf{- 9 . 8}$ & 0.1 & -4.1 & 0.9 & -1.3 & 0.6 & -6 & $\mathbf{7 . 1}$ \\
Korea & $\mathbf{6 . 1}$ & -0.5 & 2.5 & 0.5 & -2.1 & 1.4 & 4.3 & $\mathbf{- 1 1 . 5}$ \\
\hline & & & & & & & & \\
average & $\mathbf{- 8 . 3}$ & 0.0 & -3.6 & 0.3 & -2.4 & 0.5 & -3.1 & $\mathbf{1 9 . 8}$
\end{tabular}

